\title{
Effects of hot water, UV-C and modified coconut oil treatments on suppression of anthracnose disease and maintenance of quality in harvested mango cv. 'Chok-Anan'
}

\author{
Kanlaya Sripong ${ }^{1}$, Pongphen Jitareerat ${ }^{1, ~}$, Apiradee Uthairatanakij ${ }^{1}$, Varit Srilaong ${ }^{1}$, \\ Chalermchai Wongs-Aree ${ }^{1}$, Shinji Tsuyumu ${ }^{2}$, Masaya Kato ${ }^{2}$ \\ ${ }^{1}$ Division of Postharvest Technology, School of Bioresources and Technology, King Mongkut's University of Technology Thonburi, 126 \\ Bangmod, Thungkru, Bangkok, 10140, Thailand \\ ${ }^{2}$ Faculty of Agriculture, Shizuoka University, 836 Ohya, Suruga-ku, Shizuoka, 422-8529, Japan
}

\section{Email address:}

n_s_kan@hotmail.com (K. Sripong), pongphen.jit@kmutt.ac.th (P. Jitareerat), apiradee.uth@kmutt.ac.th (A. Utairatakij), varit.sri@kmutt.ac.th (V. Srilaong), chalermchai.won@kmutt.ac.th (C. Wongs-Aree), steubs0706@gmail.com (S. Tsuyumu), amkato@ipc.shizuoka.ac.jp (M. Kato)

\section{To cite this article:}

Kanlaya Sripong, Pongphen Jitareerat, Apiradee Uthairatanakij, Varit Srilaong, Chalermchai Wongs-Aree, Shinji Tsuyumu, Masaya Kato. Effects of Hot Water, UV-C and Modified Coconut Oil Treatments on Suppression of Anthracnose Disease and Maintenance of Quality in Harvested Mango cv. 'Chok-Anan'. Journal of Food and Nutrition Sciences. Special Issue: Food Processing and Food Quality. Vol. 3, No. 1-2, 2015, pp. 1-8. doi: 10.11648/j.jfns.s.2015030102.11

\begin{abstract}
Anthracnose disease caused by Colletotrichum gloeosporioides Penz. is the major problem of harvested mango for domestic markets and for export. Control of anthracnose disease is currently based on the application of fungicides. However, it was reported that there are some chemical residues of chemical in mango and in the environment. Therefore, safe alternative methods for controlling anthracnose disease were studied. The aim of this experiment was to evaluate the antifungal properties of modified coconut oil (MCO) in vitro test and to investigate the combined effects of ethanolic shellac - modified coconut oil solution (ES-MCO), hot water (HW) and UV-C treatments on controlling anthracnose disease and maintaining postharvest quality of mango fruit cv. Chok-Anan (in vivo test). The antifungal activity of the MCO was determined by a paper disc method and tested the survival of MCO treated-fungal spores on PDA. The results revealed that $2 \%$ MCO significantly inhibited the mycelail growth of $C$. gloeosporioides on paper disc and completely killed fungal spore on PDA. In vivo test, harvested mangoes were cleaned with a solution of $100 \mathrm{ppm}$ sodium hypochlorite and air dried. The fruit were treated with HW, UV-C followed by ES-MCO coating (HW + UV-C + ES-MCO), HW followed by UV-C (HW + UV-C), or ES-MCO alone. Untreated fruit served as the control. All fruit samples were then kept at $13^{\circ} \mathrm{C}$ for 15 days. $\mathrm{HW}+\mathrm{UV}-\mathrm{C}+\mathrm{ES}-\mathrm{MCO}$ treatments showed the most effective in reducing anthracnose disease, followed by HW + UV-C treatments, and ES-MCO treatment, while the control fruit showed the greatest symptoms of anthracnose disease. In addition, both the ES-MCO alone and the combined treatments of HW + UV-C + ES-MCO significantly delayed ripening of fruit by retarding firmness, weight loss, total soluble solids (TSS), titratable acidity (TA), ethylene production and respiration rate, while the peel and pulp color of mango fruit were maintained throughout the storage period. This founding shows that HW + UV-C + ES-MCO treatments may act as the safe alternative methods to suppress anthracnose disease and delayed the senescence of mango fruit during cold storage.
\end{abstract}

Keywords: Coconut Oil, Heat Treatment, Irradiation, Mangifera Indica L., Shellac

\section{Introduction}

Mango (Mangifera indica L.) is a major tropical fruit in both the domestic and export markets of Thailand, and 'ChokAnan' is one of the most popular varieties of mango in terms of planted area and production volume. Anthracnose disease caused by Colletotrichum gloeosporioides Penz. is a major problem with harvested mango. Due to the fungus is able to infect young fruit and remain latent during fruit growth in the field. Thus, it is hard to prevent disease development after harvested. Control of anthracnose disease is currently based on the application of a chemical fungicide. However, several fungicides have been problems related to development of 
pathogen resistance and potentially harmful effects on the environment and human health [1]. Therefore, safe alternative treatments have become an essential requirement for the management of postharvest disease of fruit.

Pre-storage with hot water treatment has potential as a non chemical method. Hot water treatment was shown to be efficient for controlling postharvest diseases by directly inhibiting pathogen and activating the natural resistance of the host [2, 3]. Recently, it has been reported that hot water treatment can be applied effectively to suppress postharvest disease in fresh produce, such as papaya [4], peach nectarine, plum [5] and citrus [6]. Moreover, hot water treatment has been reported to maintain the quality of fruit. For example, hot water treatment delayed fruit softening in muskmelon [7], increased the soluble solids concentration in strawberry [8] and decreased titratable acidity in eggplants [9].

UV-C has also emerged as an alternative method to avoid chemical fungicides. Application of UV-C irradiation reduce postharvest disease in several fresh produce such as bell pepper [10], strawberry [8], tomato [11] and eggplants [9], also maintain the quality of fresh produce like, delayed softening in tomato [12], mango [13], and strawberry [8], delayed chlorophyll degradation in banana [14] and broccoli [15].

Wax coating is new methods to extend the postharvest shelf life of fresh produce [16]. They are improving appearance, reduce weight loss and respiration rate. Shellac wax is produced from an insect (Laccifer lacca) has been used in prolong the shelf life of fresh produces such as chili [17] and oranges [18]. In previous studies, have been made to develop shellac surface coatings by incorporating functional ingredients such as starch, EDTA, sodium alginate for extended shelf life of chili [17] and aloe gel to maintaining the quality of apple slices [19].

Coconut oil is edible oil extracted from the kernel or meat of matured coconut palm (Cocos nucifera L.). In recent studies suggests that the coconut oil are very important source of fatty acids, mainly including luric acid, which have high antimicrobial activity [20]. Modified coconut oil (MCO) was obtained from conversion fatty acids of coconut oil to monoglycerides by glycerolysis technique. Numerous monoglycerides have been reported to inhibit a wide range of microorganism [21, 22, 23]. The incorporation of MCO in shellac for the coating of postharvest fruit may greatly to control disease and maintenance the quality of fruit.

The objective of this study was to evaluate the antifungal properties of $\mathrm{MCO}$ in vitro test and to investigate the application of HWT, UV-C irradiation and ethanolic shellacmodified coconut oil (ES-MCO) on controlling anthracnose disease and maintaining postharvest quality of mango fruit cv. 'Chok-Anan'.

\section{Materials and Methods}

\subsection{Plant Material}

Naturally infected mango fruit cv. 'Chok-Anan' were harvested from commercial orchards at $75-80 \%$ maturity. The fruit were selected for uniformity of size, shape and freedom from any defects, and then disinfected with a solution of 100 ppm sodium hypochlorite and air dried at ambient temperature.

\subsection{Fungal Isolation and Culture Conditions}

C. gloeosporioides was isolated from natural infected mango fruit and cultured on potato dextrose agar (PDA) at $27^{\circ} \mathrm{C}$ for 2 weeks. The selected colony from PDA was then be transferred to the new media for 7 days and the conidia harvested from the media to prepare the spore suspension. Fungal spores were obtained by flooding the surface of the culture with sterile distilled water containing $0.05 \%(\mathrm{v} / \mathrm{v})$ Tween-20. The suspension was filtered through four layers of sterile cheesecloth and adjusted to a concentration of $1 \mathrm{x}$ $10^{6}$ spore/mL using a hemocytometer.

\subsection{Modified Coconut Oil (MCO) and Ethanolic Shellac-Modified Coconut Oil (ES-MCO)}

MCO and ES-MCO (ES-MCO prepared from 2\% MCO and $8 \%$ shellac, dissolved in $95 \%$ ethanol) were obtained from Department of Pharmaceutical Technology, Faculty of Pharmacy, Silpakorn University.

\subsection{In Vitro Test Effect of Antifungal Activity of MCO, Shellac (SH), MCO Plus Shellac (MCO + SH) and 95\% Ethanol (ETOH) on the Mycelial Growth and Survival of Spores of $C$. gloeosporioides}

Paper disc method was used to test the effects of $\mathrm{MCO}, \mathrm{SH}$, $\mathrm{MCO}+\mathrm{SH}$ and $95 \% \mathrm{ETOH}$ on the mycelial growth of $C$. gloeosporioides. A $100 \mu \mathrm{L}$ of spore suspension of $C$. gloeosporioides, cultured in potato dextrose broth, was dropped on to black paper, dried on air at $25^{\circ} \mathrm{C}$ for $3 \mathrm{~min}$, and then dropped with $100 \mu \mathrm{L}$ of $2 \% \mathrm{MCO}, 8 \% \mathrm{SH}, 2 \% \mathrm{MCO}+$ $8 \% \mathrm{SH}$ and $95 \%$ ETOH on the same position. Dipping with sterile distilled water was used as the control. The paper discs treated was placed in a high moisture chamber (100\%) for 2 weeks. After that, observed the fungal mycelium on paper disc. Each treatment contained three replicates and each replicate consisted of 4 paper disc.

The survival of fungal spores was evaluated by cutting the paper discs tested into small pieces $(1 \times 1 \times 1 \times 1 \mathrm{~cm})$. These paper discs were then placed onto the surface of PDA plates, and incubated at $25^{\circ} \mathrm{C}$ for 2 weeks. Germination of fungal spores on PDA was interpreted as an indication of the survival of the fungal spores. Each treatment contained three replicates and each replicate consisted of 4 plates.

\subsection{Effect of Combination of HW, UV-C and ES-MCO Treatments on Anthracnose Disease of Naturally Infected in Mango Fruit}

Fruit were randomly grouped into four groups: surface coated with ES-MCO (ES-MCO), dipped in hot water followed by UV-C irradiation (HW + UV-C), dipped in hot water followed by UV-C and then surface coated with ESMCO (HW + UV-C + ES-MCO), and untreated as the control. 
The fruit were dipped in ES-MCO for $1 \mathrm{~min}$ and allowed to dry in air at ambient temperature. HW was conducted by submersing the fruit in hot water at $55^{\circ} \mathrm{C}$ for $5 \mathrm{~min}$. After treatment the fruit were immediately cooled in cold tap water $\left(10^{\circ} \mathrm{C}\right)$ for $15 \mathrm{~min}$, and then air dried at ambient temperature. UV-C irradiation was provided using General Electric $30 \mathrm{~W}$ G15T8 germicidal lamps. Mango fruit were placed under the UV-C lamps, on aluminum foil for light reflection, at a distance of $50 \mathrm{~cm}$ from the light source for $2 \mathrm{~min}$ to provide a dose of $6.16 \mathrm{~kJ} / \mathrm{m}^{2}$. The UV-C dose was measured with a digital radiometer (Cole-Parmer Instrument Company, Vernon Hills, IL, USA). In the case of the combination treatments, mango fruit were dipped in hot water, cooled, dried, irradiated with UV-C, and then surface coated with ES$\mathrm{MCO}$ as described above.

After treatment, All fruit samples were placed in plastic basket covered within a polyethylene bag (PE) and kept at $13^{\circ} \mathrm{C}$ under humidified conditions $(85-90 \% \mathrm{RH})$ for 15 days. Each treatment contained three replicates and each replicate consisted of 4 fruit.

\subsection{Evaluation of Disease Incidence and Severity}

Disease incidence of mango fruit was evaluated as a percentage of the total number of infected fruit subjected to each treatment. The severity of disease was assessed by the extent of total decayed area on each fruit surface using a 5point scale, where $0=$ no disease symptoms, $1=1-10 \%$ of disease spots, $2=10-20 \%$ of disease spots, $3=20-30 \%$ of disease spots, $4=30-40 \%$ of disease spots, $5=>40 \%$ of disease spots on the affected mango fruit surface [24].

\subsection{Determination of Fruit Quality}

After treatment and storage at $13^{\circ} \mathrm{C}$ for 15 days, fruit were evaluated for weight loss, firmness, total soluble solids concentration (TSS), titratable acidity (TA) and color. Weight loss was determined as a percentage of the initial weight. Flesh fiacidit was measured by texture analyzer (model TAXT2), equipped with a cylindrical plunger $8 \mathrm{~mm}$ diameter. TSS was determined using an Atago-N1 refractometer (10481 S/N, USA) and TA was determined using the titrimetric method with $0.1 \mathrm{~N} \mathrm{NaOH}$ and phenolphthalein as the indicator. Changes in peel and pulp color were

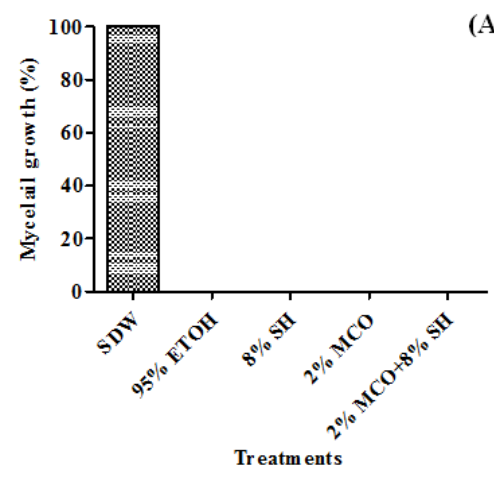

determined using a Minolta DP-301 colorimeter measuring the $a^{*}, b^{*}, L^{*}$ values and hue angle. Each treatment contained three replicates and each replicate consisted of 4 fruits.

\subsection{Determination of Ethylene Production and Respiration Rate}

Three fruits were sealed in a respiration jar for $2 \mathrm{~h}$ at $25^{\circ} \mathrm{C}$. A $1 \mathrm{~mL}$ gas sample was taken from each group of three fruit using a syringe and injected into the Shimadzu GC-8A gas chromatograph with thermal conductivity detector and molecular sieve $5 \mathrm{~A}$ column at $50^{\circ} \mathrm{C}$ for $\mathrm{CO}_{2}$ analysis and Shimadzu GC-14B with flame ionization detector and Porapak Q column at $50^{\circ} \mathrm{C}$ for ethylene analysis. Three replications for each treatment were performed.

\subsection{Statistical Analysis}

Results were analyzed by conducting analysis of variance using the general linear models procedure of SAS (SAS Institute, Cary, N.C.) for completely randomized design experiments. Data are presented as means \pm standard errors of the means.

\section{Results}

\subsection{In Vitro Test Effect of MCO, SH, MCO + SH and 95\% ETOH on Mycelail Growth and Survival of $C$. gloeosporioides}

The in vitro antifungal activities of $2 \% \mathrm{MCO}, 8 \% \mathrm{SH}$, $2 \% \mathrm{MCO}+8 \% \mathrm{SH}$ and $95 \% \mathrm{ETOH}$ on mycelail growth of $C$. gloeosporioides were evaluated by using paper disc method. The results found that $2 \% \mathrm{MCO}, 8 \% \mathrm{SH}, 2 \% \mathrm{MCO}+8 \% \mathrm{SH}$ and $95 \%$ ETOH treatments completely inhibited the mycelail growth of $C$. gloeosporioides on paper disc, while control treated showed $100 \%$ of mycelail growth (Figure 1A). The survival of fungal spore was observed by cutting the paper disc treated and cultured on PDA at $25^{\circ} \mathrm{C}$ for 2 weeks. The results found that $2 \% \mathrm{MCO}$ and $2 \% \mathrm{MCO}+8 \% \mathrm{SH}$ treated showed completely killed spore of C. gloeosporioides on PDA plate. While, $95 \%$ ETOH and $8 \% \mathrm{SH}$ treated did not kill fungal spores as same as the control (Figure 1B).

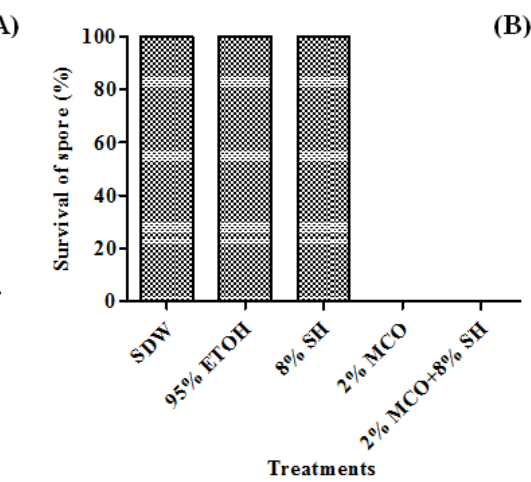

Figure 1. Mycelial growth (A) and survival of spore (B) of C. gloeosporioides after treated with sterile distilled water (SDW or Control), 95\% ETOH, 8\% SH, $2 \% \mathrm{MCO}$ and $2 \% \mathrm{MCO}+8 \% \mathrm{SH}$ by paper dice method and storage at $25^{\circ} \mathrm{C}$ for 2 weeks. Vertical bars represent \pm SE for triplicate samples. 


\subsection{Effect of Combination of $H W, U V-C$ and $E S-M C O$ Treatments on Disease Incidence and Disease Severity in Mango Fruit}

The combinations of HW + UV-C + ESMC significantly reduce both disease incidence and severity in mango fruit. Disease incidence in control fruit showed faster than other treatments. On day 6 of storage the control fruit had $40 \%$ incidence while the fruit treated with ES-MCO, HW+UV-C and HW + UV-C + ES-MCO did not show visible decay until

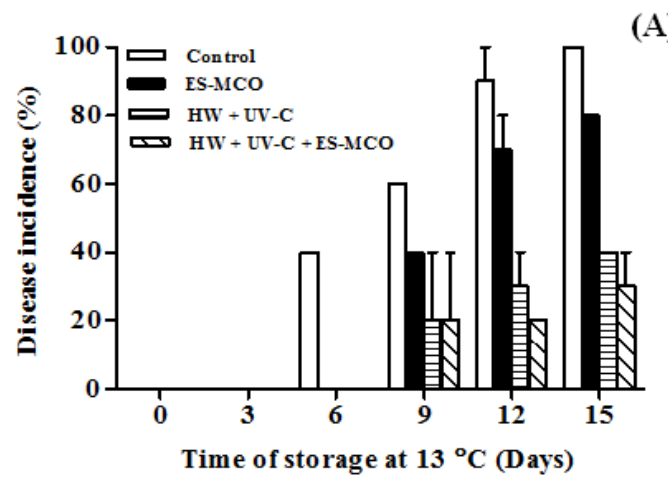

day 9 . By the end of storage (15 days) the control fruit had $100 \%$ disease incidence, followed by fruit treated with ESMCO (80\%), HW + UV-C (40\%) and HW + UV-C +ESMCO (30\%) respectively (Figure 2A). Similarly, disease severity at the end of storage was lowest in the fruit treated with HW + UV-C + ES-MCO ( 0.5 score $)$, followed by HW + UV-C (0.66 score), ES-MCO (1.16 score), while the control fruit showed the highest severity (3 score) (Figure 2B).

(A)

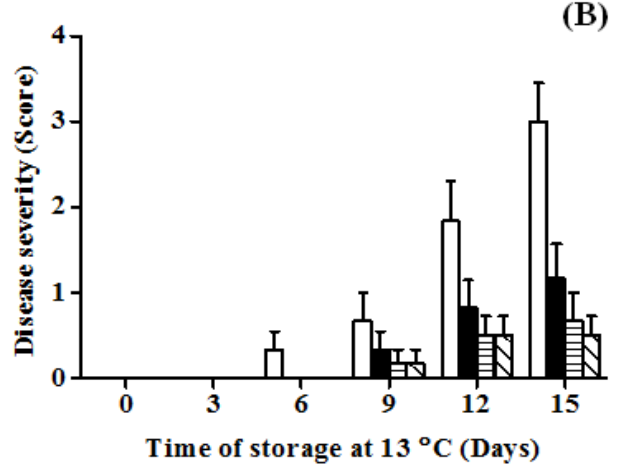

Figure 2. Incidence (A) and severity (B) of anthracnose disease of mango fruit 'Chok-Anan' when surface-coated with ES-MCO (ES-MCO), dipped in hot water at $55^{\circ} \mathrm{C}$ for 5 min followed by $U V$-C irradiation at $6.16 \mathrm{KJ} / \mathrm{m}^{2}(\mathrm{HW}+U \mathrm{~V}-\mathrm{C})$, dipped in hot water at $55^{\circ} \mathrm{C}$ for 5 min followed by $U V-C$ irradiation at 6.16 $\mathrm{KJ} / \mathrm{m}^{2}$ and surface-coated with ES-MCO (HW+UV-C $\left.+E S-M C O\right)$ and untreated (Control) during storage at $13^{\circ} \mathrm{C}$ for 15 days. Vertical bars represent $\pm S E$ for triplicate samples.

\subsection{Effect of Combination of HW, UV-C and ES-MCO Treatments on Quality of Mango Fruit}

Weight loss of mango fruit in all treatments increased progressively with extended storage time. HW combined with UV-C and ES-CMO significantly reducing weight loss as same as fruit treated ES-MCO alone. This was followed by the fruit treated with combination of HW and UV-C, while the control fruit showed the highest percentage weight loss (Figure 3A).

Fruit firmness was reduced in all treatments with increasing periods of storage time. In the first 6 days of storage, there were no significant differences among the treatments. Subsequently, the control and combined HW and UV-C treated fruit softened the most rapidly, while the fruit treated with ES-CMO alone showed more pronounced effects as compared to the HW combined with UV-C and control fruit. However, when used in HW combined with UV-C and ES-CMO showed the most effective to delayed decreased in firmness fruit (Figure 3B).

Titratable acidity concentration (TA) decreased slightly with storage time. Significantly difference in TA were noted after 9 days of storage and thereafter the HW combined with UV-C and ES-CMO had higher levels than those ES-CMO, combination of HW and UV-C, and control fruit respectively (Figure 3C). In contrast, total soluble solids (TSS) concentration increased with storage time and found that the lowest levels in the HW treatment combined with UV-C and ES-CMO as the compared to the other treatments (Figure $3 \mathrm{D})$.

The fruits treated with ES-CMO alone and combination of HW combined with UV-C and ES-CMO could delay color change (indicated by the values of $a^{*}, b^{*}, L^{*}$ and Hue angle) in mango fruit better than the control fruit. In contrast, the fruit treated with combination of $\mathrm{HW}$ and UV-C was increased yellowing as well as the control (Figure 4A-4D).

\subsection{Effect of Combination of HW, UV-C and ES-MCO Treatments on Ethylene Production and Respiration Rate}

Ethylene productions were tending to stable during the first 9 days of storage. Afterwards, increased rapidly in all treatments and highest ethylene production were detected in the control and the combination of HW and UV-C. The ethylene production was significant reduced after treated with ES-CMO alone as well as the HW combined with UV-C and ES-CMO (Figure 5A). Similarly, respiration rate did not showed much change during the first 9 days of storage. Afterwards, the control and the combination of HW and UV$\mathrm{C}$ were increased rapidly while, the respiration rate was significantly decreased after treated with ES-CMO as well as the HW combined with UV-C and ES-CMO treatments (Figure 5B). 

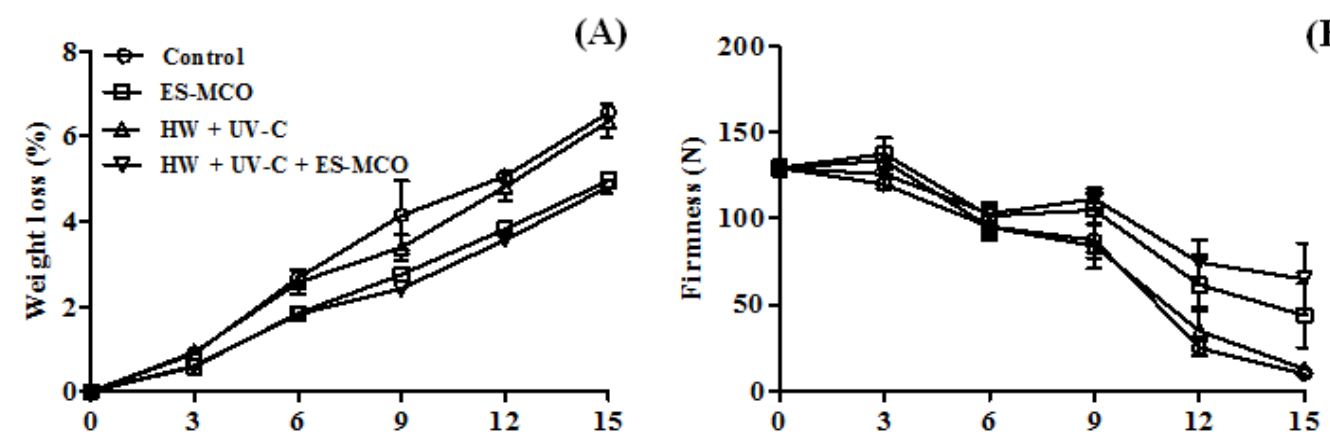

(B)
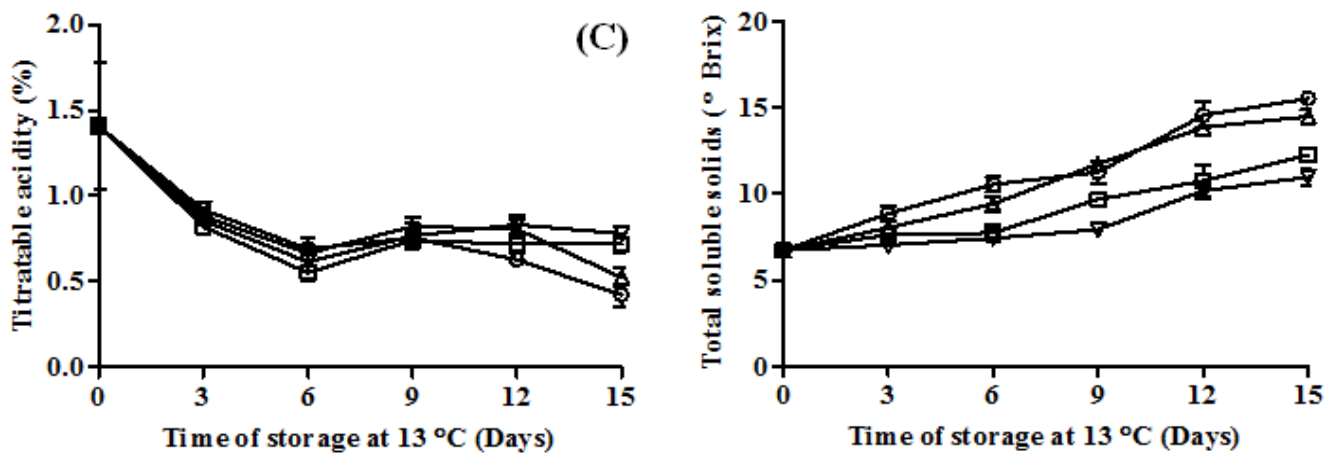

(D)

Figure 3. Weight loss (A), Firmness (B), Titratable acidity (C) and Total soluble solids (D) of mango fruit 'Chok-Anan' when surface-coated with ES-MCO (ES-MCO), dipped in hot water at $55^{\circ} \mathrm{C}$ for 5 min followed by $U V$-C irradiation at $6.16 \mathrm{KJ} / \mathrm{m}^{2}(\mathrm{HW}+U V-C)$, dipped in hot water at $55^{\circ} \mathrm{C}$ for $5 \mathrm{~min}$ followed by UV-C irradiation at $6.16 \mathrm{KJ} / \mathrm{m}^{2}$ and surface-coated with ES-MCO $(\mathrm{HW}+U \mathrm{U}-\mathrm{C}+\mathrm{ES}-\mathrm{MCO})$ and untreated (Control) during storage at $13^{\circ} \mathrm{C}$ for 15 days. Vertical bars represent \pm SE for triplicate samples.

(A)
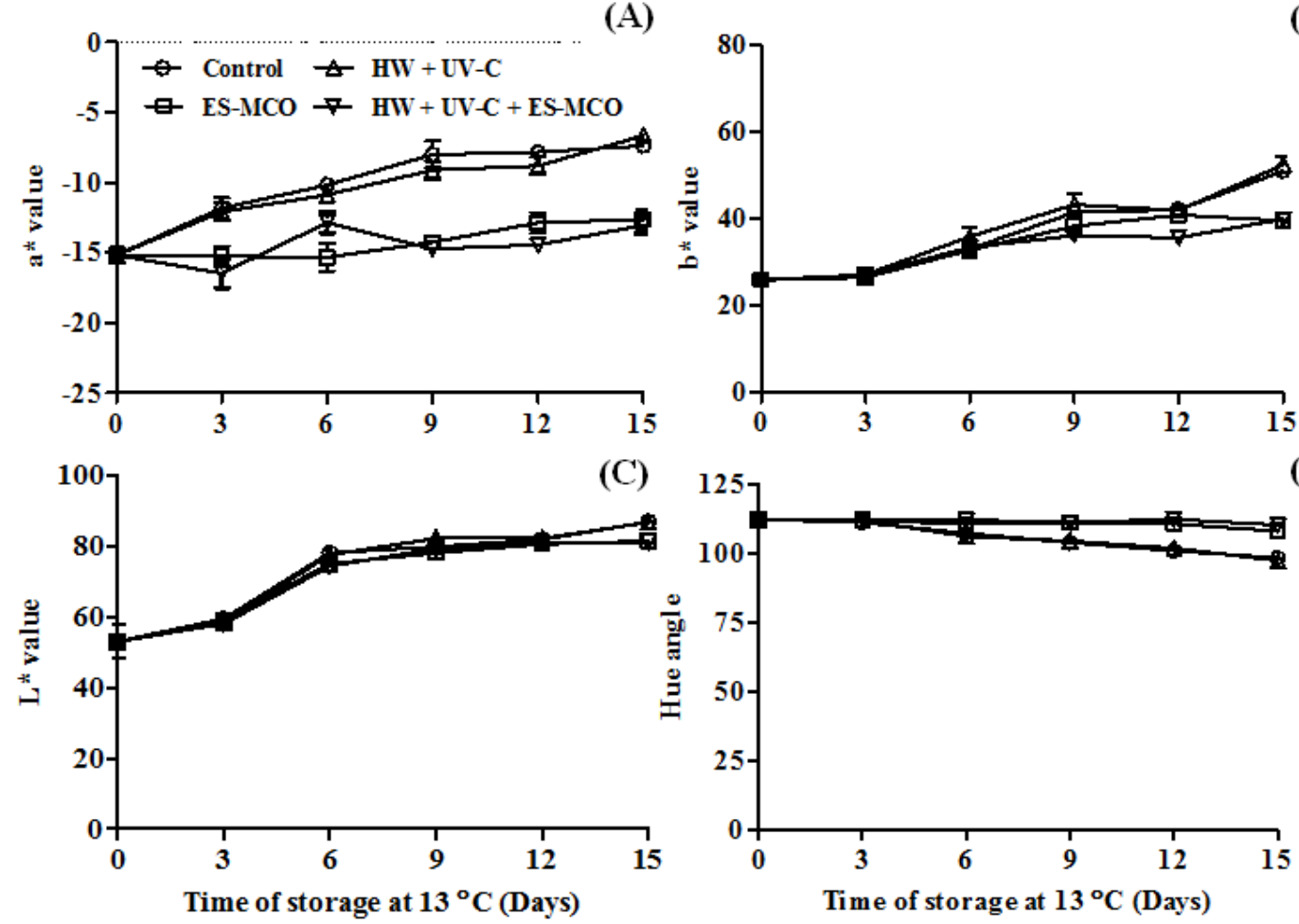

(B)

(D)

Figure 4. Chang of color in peel of mango fruit 'Chok-Anan $a^{*}(A), b^{*}(B), L^{*}$ value $(C)$ and hue angle (D) when surface-coated with ES-MCO (ES-MCO), dipped in hot water at $55^{\circ} \mathrm{C}$ for 5 min followed by $U V$-C irradiation at $6.16 \mathrm{KJ} / \mathrm{m}^{2}(\mathrm{HW}+U \mathrm{~V}-\mathrm{C})$, dipped in hot water at $55^{\circ} \mathrm{C}$ for $5 \mathrm{~min}$ followed by $U V$-C irradiation at $6.16 \mathrm{KJ} / \mathrm{m}^{2}$ and surface-coated with ES-MCO $(H W+U V-C+E S-M C O)$ and untreated (Control) during storage at $13^{\circ} \mathrm{C}$ for 15 days. Vertical bars represent $\pm S E$ for triplicate samples. 

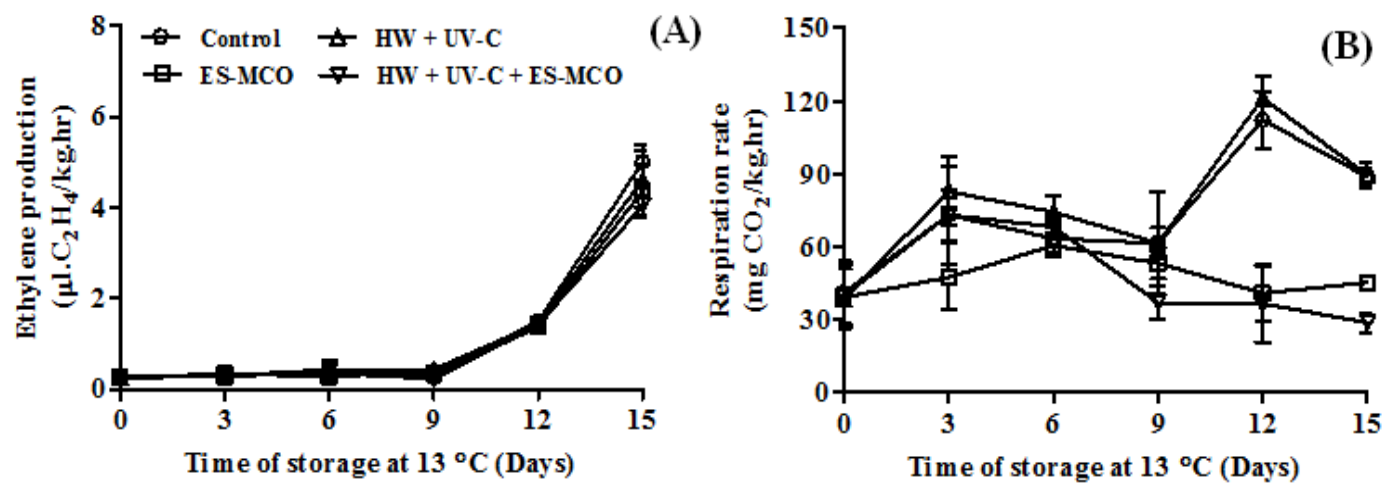

Figure 5. Ethylene production (A) and respiration rate (B) of mango fruit 'Chok-Anan' when surface-coated with ES-MCO (ES-MCO), dipped in hot water at $55^{\circ} \mathrm{C}$ for 5 min followed by $U V$-C irradiation at $6.16 \mathrm{KJ} / \mathrm{m}^{2}\left(\mathrm{HW}+U V\right.$-C), dipped in hot water at $55^{\circ} \mathrm{C}$ for 5 min followed by $U V$-C irradiation at $6.16 \mathrm{KJ} / \mathrm{m}^{2}$ and surface-coated with ES-MCO $(H W+U V-C+E S-M C O)$ and untreated (Control) during storage at $13^{\circ} \mathrm{C}$ for 15 days. Vertical bars represent $\pm S E$ for triplicate samples.

\section{Discussion}

Mangoes are a climacteric fruit with a limited shelf life, the quality of the fruit rapidly decreases once fully ripe, and sensitive to pathogen infection. In our previous studies, we found that the combination treatment of HW and UV-C irradiation could help to control anthracnose disease on mango fruit. However, the mango fruit treated with the combination treatment was increased weight loss higher than the control fruit during storage at $13^{\circ} \mathrm{C}$. Thus, in this study were used the ES-MCO coating combined with HW and UV$\mathrm{C}$ treatments to improve the quality of mango fruit. ES-MCO coating were used in this study containing $2 \% \mathrm{MCO}, 8 \% \mathrm{SH}$ and used $95 \% \mathrm{ETOH}$ as the solvent.

$\mathrm{MCO}$ is the process from conversion triglycerides of coconut oil to monoglyceride by glycerolysis technique. Monoglycerides are derivates of fatty acids, many researchers thought its mode of action may be similar to fatty acids [25]. In previous studies, reported that monoglycerides and fatty acids are small enough to be readily dissolved in the lipid phase, to penetrate and physically disrupt cell membranes, and to inhibit enzymes involved in energy production and nutrient transfer, leading to reversible and irreversible changes that may lead to the death of the cell [25]. In the present study, investigate the effect of antifungal activity of MCO by compared with $8 \% \mathrm{SH}$ and $95 \% \mathrm{ETOH}$ on mycelial growth of $C$. gloeosporioides by paper disc method, this result found that the all of $2 \% \mathrm{MCO}, 8 \% \mathrm{SH}$, $2 \% \mathrm{MCO}+8 \% \mathrm{SH}$ and $95 \%$ ETOH could inhibit mycelail growth of $C$. gloeosporioides on paper disc. However, when observed the survival of fungal spores on PDA plate, only $2 \% \mathrm{MCO}$ and $2 \% \mathrm{MCO}+8 \% \mathrm{SH}$ could inhibit spore germination of $C$. gloeosporioides on PDA, this result confirmed that $2 \% \mathrm{MCO}$ was the main effected to inhibit the mycelial growth and killed spore of C. gloeosporioides. Similar, reported of [26] found that, monoglyceride prepared from coconut oil inhibited radial growth and spore germination of Aspergillus niger.

The application of HW combined with UV-C and ESMCO coating was studied on control of anthracnose disease in mango fruit. This result found that, application of $\mathrm{HW}+$ UV-C + ES-MCO showed beneficial effect on the control of anthracnose disease. It have been reported that the effect of $\mathrm{HW}$ and UV-C on the reduction of anthracnose disease could be attributed to different causes. A direct detrimental effect of the HW and UV-C irradiation on the fungus present on the fruit surface is possible, an indirect effect by inducing defense mechanisms in the plant tissue. Furthermore, coated surface of mango with ES-MCO could barrier against pathogenic infection, concurrently a coating material containing MCO, which MCO are very important source of monoglycerides, and have high antimicrobial activity [26, 27].

Mangoes fruit was a typical of climacteric fruit. It is ripening and senescence processes it regulated by the plant hormone ethylene responsible for bringing changes in physiological and biochemical attributes such as enzyme activity associated with tissue softening and pigment degradation. Application of HW combined with UV-C and ES-MCO showed the most effective on reduced ethylene production and respiration rate. [28] reported that film coatings can create modified atmosphere, similar to that of modified atmosphere storage, could be attributed to the reduced oxygen uptake by the coated fruits, thereby lowering the respiration rate and ethylene production of fruit. Reduction of the respiration rate as a result of coating with film has also been reported for tomato [28], avocado [29], strawberry [30] and litchi [31].

Color and textures of fruit are two physical quality parameters that affect consumer acceptability. The mango fruit coated with ES-MCO could delay color change of mango fruit and maintain fruit firmness than the fruit treated with combination of $\mathrm{HW}$ and $\mathrm{UV}-\mathrm{C}$ and the control fruit. However, HW combined with UV-C and ES-MCO showed the most effective than the fruit treated with ES-MCO alone. The lower color changes in coated fruit may be related to the effect of coating in creating modified atmospheres within the fruit. The presence of $\mathrm{CO}_{2}$ in the storage atmosphere is an important factor in preventing chlorophyll degradation [28]. High oxygen concentrations created by coating reduce the 
activities of these enzymes and allows retention of the firmness of fruit during storage [32]. In addition, UV-C could be associated with the effect of the radiation on the activity of enzymes involved in cell wall degradation [12] and preventing chlorophyll degradation $[14,15]$.

Moreover, the combination of HW, UV-C and ES-MCO maintained the changes in TA and TSS concentration. According to [33] acidity decreases as mangoes ripen, as citric and malic acid are used as respiratory substrates. This result was inversely correlated with TSS increase during storage from mature-green to the full ripe stage. Increased TSS may be related to moisture loss and to polysaccharides hydrolysis.

\section{Conclusions}

In conclusion, the data presented here show that $\mathrm{MCO}$ significantly inhibited spore germination and completely killed spore of $C$. gloeosporioides, a causal agent of anthracnose disease in mangoes. The combination treatment of HW, UV-C and ES-MCO is more effective to reduce anthracnose disease and delay fruit senescence than the single treatment. Their application could be a promising, innovative and alternative approach to the use of chemicals for the control of postharvest diseases and the maintenance of quality in mango fruit for both domestic and for export markets.

\section{Acknowledgements}

The first author was financially supported by the Thailand Research Fund through the Royal Golden Jubilee Ph.D. Program (RGJ) (Grant No. PHD/00642554). This work was also supported by the Higher Education Research Promotion and National Research University Project of Thailand, Office of the Higher Education Commission. The author would like to thank Assoc. Prof. Dr. Sontaya Limmatvapirat, Department of Pharmaceutical Technology, Faculty of Pharmacy, Silpakorn University for providing MCO and ES$\mathrm{MCO}$.

\section{References}

[1] Z. Ma and T. J. Michailides, "Advances in understanding molecular mechanisms of fungicide resistance and molecular detection of resistant genotypes in phytopathogenic fungi," Crop Prot., vol. 24, pp. 853-863, 2005.

[2] R. Porat, A. Lers, S. Dori, L. Cohen, S. Ben-Yehoshua, E. Fallik, S. Droby, and S. Lurie, "Induction of resistance against Penicillium digitatum and chilling injury in star ruby grapefruit by a short hot water-brushing treatment," J. Hort. Sci. Biotech, vol. 75, pp. 428-432, 2000.

[3] B. Nafussi, S. Ben-Yehoshua, V. Rodov, J. Peretz, B. K. Ozer, and G. D'hallewin, "Mode of action of hot water dip in reducing decay in lemon fruit," J. Agri. Food, vol. 49, pp. $107-113,2001$
[4] X. Li, X. Zhu, N. Zhao, D. Fu, J. Li, W. Chen, and W. Chen, "Effects of hot water treatment on anthracnose disease in papaya fruit and its possible mechanism," Postharvest Biol. Technol., vol. 86, pp. 437-446, 2013.

[5] O. A. Karabulut, J. L. Smilanick, C. H. Crisosto, and L. Palou, "Control of brown rot of stone fruits by brief heated water immersion treatments," Crop Prot., vol. 29, pp. 903-906, 2010.

[6] S. Hong, H. Lee, and D. Kim, "Effects of hot water treatment on the storage stability of satsuma mandarin as a postharvest decay control," Postharvest Biol. Technol., vol. 43, pp. 271279, 2007.

[7] L. Yuan, Y. Bi, Y. Ge, Y. Wang, Y. Liu, and G. Li, "Postharvest hot water dipping reduces decay by inducing disease resistance and maintaining firmness in muskmelon (Cucumis melo L.) fruit," Sci. Horticult., vol. 161, pp. 101-110, 2013.

[8] M. A. Pombo, H. G. Rosli, G. A. Martinez, and P. M. Civello, "UV-C treatment affects the expression and activity of defense genes in strawberry fruit (Fragaria $\times$ ananassa, Duch.)," Postharvest Biol. Technol., vol. 59, pp. 94-102, 2011.

[9] I. Karasahin, M. Pekmezco, and M. Erkan, "Combined hot water and UV-C treatments reduces postharvest decay and maintains quality of eggplants," Postharvest Technol., vol. 5, pp. 12-16, 2005.

[10] J. Mercier, M. Baka, B. Reddy, R. Corcuff, and J. Arul, "Short-wave ultraviolet irradiation for control of decay by Botrytis cinerea in bell pepper: induced resistance and germicidal effects," J. Am. Soc. Hort. Sci., vol. 126, pp. 128 $133,2001$.

[11] S. Cote, L. Rodoni, E. Miceli, A. Concellona, and P. M. Civello, "Effect of radiation intensity on the outcome of postharvest UV-C treatments," Postharvest Biol. Technol., vol. 83, pp. 83-89, 2013.

[12] E. A. Barka, S. Kalantari, J. Malhlouf, and J. Arul, "Impact of UV-C irradiation on the cell wall-degrading enzymes during ripening of tomato (Lycopersicon esculentum L.) fruit," J. Agric. Food. Chem., vol. 48, pp. 667-671, 2000.

[13] G. A. Gonzalez-Aguilar, R. Zavaleta-Gatica, and M. E. Tiznado-Hernandez, "Improving postharvest quality of mango 'Haden' by UV-C treatment," Postharvest Biol. Technol., vol. 45, pp. 108-116, 2007.

[14] N. Pongprasert, Y. Sekozawa, S. Sugaya, and H. Gemma, “A novel postharvest UV-C treatment to reduce chilling injury (membrane damage, browning and chlorophyll degradation) in banana peel," Sci. Horticult., vol. 130, pp. 73-77, 2011.

[15] L. Costa, A. R. Vicente, P. M. Civello, A. R. Chaves, and G. A. Martinez, "UV-C treatment delays postharvest senescence in broccoli florets," Postharvest Biol. Technol., Vol. 39, pp. 204$210,2006$.

[16] G. I. Olivas, D. S. Mattinson, and G. V. Barbosa-Canovas, "Alginate coatings for preservation of minimally processed "Gala" apples," Postharvest Biol. Technol., vol. 45, pp. 89-96, 2007.

[17] K. Chitravathi, O. P. Chauhan, and P. S. Raju, "Postharvest shelf-life extension of green chillies (Capsicum annuum L.) using shellac-based edible surface coatings," Postharvest Biol. Technol., vol. 92, pp. 146-148, 2014. 
[18] R. Lahlali, Y. Hamadi, R. Drider, C. Misson, M. El Guilli, and M. H. Jijakli, "Control of citrus blue mold by the antagonist yeast Pichia guilliermondii Z1:Compatibility with commercial fruit waxes and putative mechanisms of action," Food Control, vol. 45, pp. 8-15, 2014.

[19] O. P. Chauhan, P. S. Raju, A. Singh, and A. S. Bawa, "Shellac and aloe-gel-based surface coatings for maintaining keeping quality of apple slices," Food Chem., vol. 126, pp. 961-966, 2011.

[20] M. DebMandal and S. Mandal, "Coconut (Cocos nucifera L.: Arecaceae): In health promotion and disease prevention," Asian Pac. J. Trop. Med., vol.1, pp. 241-247, 2011.

[21] I. Hauerlandova, E. Lorencova, F. Bunka, J. Navratil, K. Janeckova, and L. Bunkova, "The influence of fat and monoacylglycerols on growth of spore-forming bacteria in processed cheese," Int. J. Food Microbiol., vol. 182-183, pp. 37-43, 2014.

[22] M. K. M. Nair, P. Vasudevan, T. Hoagland, and K. Venkitanarayanan, "Inactivation of Escherichia coli $\mathrm{O} 157: \mathrm{H} 7$ and Listeria monocytogenes in milk by caprylic acid and monocaprylin," Food Microbiol., vol. 21, pp. 611-616, 2014.

[23] J. C. McLay, M. J. Kennedy, A. L. O'Rourke, R. M. Elliot, and R. S. Simmonds, "Inhibition of bacterial foodborne pathogens by the lactoperoxidase system in combination with monolaurin,” Int. J. Food Microbiol., vol. 73, pp. 1-9, 2012.

[24] P. Chantrasri, V. Sardsud, S. Sangchote, and U. Sardsud, "Combining yeasts and chitosan treatment to reduce anthracnose fruit rot in mangoes," Asian J. Biol. Educ., vol. 3, pp. 40-46, 2007.

[25] C. Luo, Z. Zeng, D. Gong, C. Zhao, and Q. Liang, "Evaluation of monolaurin from camphor tree seeds for controlling food spoilage fungi," Food Control, vol. 46, pp. 488-494, 2014.

[26] Z. Rihakova, V. Filip, M. Plockova, J. Smidrkal, and R. Cervenkova, "Inhibition of Aspergillus niger DMF 0801 by monoacylglycerols prepared from coconut oil," J. Food, vol. 20, pp. 48-52, 2002.

[27] L. L. Wang, B. K. Yang, K. L. Parkin, and E. A. Johnson, "Inhibition of Listeria monocytogenes by monoacylglycerols synthesized from coconut oil and milk fat by lipase-catalyzed glycerolysis," J. Agri. Food Chem., vol. 41, pp. 1000-1005, 1993.

[28] N. Maftoonazad, H. S. Ramaswamy, M. Moalemiyan, and A. C. Kushalappa, "Effect of pectin-based edible emulsion coating on changes in quality of avocado exposed to Lasiodiplodia theobromae infection," Carbohyd. Polym, vol. 68, pp. 341-349, 2007.

[29] A. Ali, M. Maqbool, P. G. Alderson, and N. Zahid, "Effect of gum arabic as an edible coating on antioxidant capacity of tomato (Solanum lycopersicum L.) fruit during storage," Postharvest Biol. Technol., vol. 92, pp. 146-148, 2014.

[30] A. Perdonesa, L. Sanchez-Gonzaleza, A. Chiralta, and M. Vargasa, "Effect of chitosan-lemon essential oil coatings on storage-keeping quality of strawberry," Postharvest Biol. Technol., vol. 70, pp. 32-41, 2012.

[31] B. Lin, Y. Dua, X. Liang, X. Wang, X. Wang, and J. Yanga, "Effect of chitosan coating on respiratory behavior and quality of stored litchi under ambient temperature," J. Food Eng., vol. 102, pp. 94-99, 2011.

[32] Y. Deng, Y. Wu, and Y. Li, "Changes in firmness, cell wall composition and cell wall hydrolyses of grapes stored in high oxygen atmospheres," Food Res. Int., vol. 38, pp. 769-776, 2005.

[33] K. K. Jacobi, E. A. Macrae, and S. E. Hetherington, "Effects of hot air conditioning of 'Kensington' mango fruit on the response to hot water treatment," Postharvest Biol. Technol., vol. 21, pp. 39-49, 2000. 